\title{
協働の観点からみた森林づくり活動の運営方法に関する研究 一滋賀県における流域森林づくり委員会活動を事例として一
}

\author{
高橋 卓也(滋賀県立大学) \\ 山㟝啓太郎（パナソニックフードアプライアンス株式会社）
}

\section{Collaboration in Managing Forests: A Case Study on Watershed Forest Committees in Shiga Prefecture}

Takuya Takahashi (The University of Shiga Prefecture)

Keitaro Yamazaki (Panasonic Food Appliances Co., Ltd.)

Forest management in Japan needs citizen collaboration under the current difficult circumstances. This paper analyzes the collaborative activities of six watershed forest committees in Shiga Prefecture. We conducted hearing research on the committee secretariats and a questionnaire survey among participants of the committees and found that the overall satisfaction levels were high among the

\section{1. 背景と目的}

森林・林業政策のなかでも, 協働（多様な地域課 題の解決やより質の高い公共サービスの実現を目的 とする住民を構成メンバーとする自主的・自発的な さまざまな活動主体をはじめ広く「民」と行政との 対等な立場での協力関係 [1]）の重要性が強調され るようになっている. 平成 23 年 7 月に閣議決定さ れた「森林・林業基本計画」では，以下のように， 国民全体による協働の必要性が強調されている.

森林の有する多面的機能の発揮のためには, 森 林の適正な整備及び保全並びに林業・木材産業 の健全な発展に向けて関係者が一体となって努 力していくだけでなく, 森林を社会全体で支光 ていこうといら機運を醸成し, 国民の幅広い理 解と具体的な行動を促すことが必要となる. (「森 林・林業基本計画」 [2]，p. 9，下線部本稿著者） また, 地方自治体においても同様の動きが存在する. 滋賀県に敃いては, 2004 年に琵琶湖森林づくり 条例が施行され，2005 年には，琵琶湖森林づくり 基本計画が策定されている。 そのなかでらたわれて いるのは，「環境重視」「県民協働」の 2 つの新たな participants and that the characteristics and styles of the committees influenced the evaluation levels reported by the respondents about committee activities. Specifically, the distinctive activities of the committee, the assignment of specific roles to members, and strong leadership most strongly influenced the evaluations.

視点に立った森林づくりである．また，他の多くの 県と同様，滋賀県では，森林環境税を導入し，広く 県民に森づくり費用の負担を求めている.

ここで，民有林に関し，協働が言及されることが 疑問となるかもしれない，私有財産である森林につ いて，とくに木材生産といら収益目的の森林である 人工林について，なぜ所有者以外の県民が関わるこ とが政策課題となっているのか，この疑問に対し簡 単に答えて扣きたい，第 2 次大戦後の日本では，民 有林に括いて人工造林が大規模に進行した，当初の 目的は自律的な産業としての林業の育成であった が，木材輸入の自由化にともなら木材価格の相対的 な下落, 生産性向上の停滞等によって, 林業の収益 性は低下した。こうした状況下，日本の人工林は公 的な支援なくしては，管理が不可能な部分が大きく なっている，人工林といえども，水源涵養，土砂災 害防止，地球温暖化防止等の環境面での公益的機能 を有している．したがって，人工林を多く含む民有 林に対しても公的な支援が必要であり，その1つの 在り方として，協働が課題となっている.

しかし，現在のところ，協働の具体的なあり方に 
ついては，日本各地に拈いて，試行錯誤を繰り返し て颃り，あるべき姿はいまだ明確になっていないと いらのが現状であろら。

すでに，森林・林業分野に打ける協働活動につい ては，理論的検討（たとえば，柿澤［3]）扣よび事例 研究（たとえば，柿澤 [4]，岡田 [5]）はいくつか存 在するが，それらの研究では，活動の過程を全体と して検討・評価して打り，参加者個々の態度まで掘 り下げた研究は管見の限り存在しない. 多様な立場 の主体が参加する協働活動に沶いて，それぞれの参 加者の態度の違いが重要であることは言うまでもな く，本研究はその点について明らかにしよらとする.

本稿では，地方自治体に打釉林づくり活動を 協働の観点から評価し，より良い運営方法について 検討することを目指す.

滋賀県では協働の森づくりを実現するための手段 の 1 つとして，滋賀県の 6 つの流域（大津, 南部, 東近江, 湖東, 湖北, 高島）に流域森林つくり委員 会が設立された。これらの委員会では，それぞれ異 なった運営方法がとられている. それぞれの委員会 の運営の成果について評価することによって，運営 方法の違いが運営の成果にどのような影響を及添す のかを探る。

\section{2. 方法}

\section{(1) 概要}

各委員会の事務局担当者への聞き取り調査によっ て，各委員会の運営方法の違いを確認する，各委員 会の委員にアンケート調査を実施し，協働といら観 点から見て, 委員会の活動について評価してもらら. また，全般的な満足度についての評価も依頼する. 運営方法の違いと各委員の評価とをクロス分析する ことによって，運営方法が評価とどのように関係し ているかを明らかにする。

\section{（2）聞き取り調査}

6 つの委員会の事務局（滋賀県職員）に聞き取り 調査を行った，6つの流域名およびそれぞれの委員 会がカバーする市町の範囲については表 1 を参照さ れたい，表 1 に示すよらに，各委員会のカバーする 区域に打㐌森林面積は約 1 万 5 千 ha から約 4 万 ha といら幅が見られる。森林率は $39 \%$ から 57\%, 人工林率は $30 \%$ から $54 \%$ に分布している. 人工林の 成熟度を示す人工林蓄積は， $199 \mathrm{~m}^{3} / \mathrm{ha}$ から $294 \mathrm{~m}^{3}$ /
表 1. 滋賀県流域森林づくり委員会と流域森林の特徵

\begin{tabular}{|c|c|c|c|c|c|}
\hline $\begin{array}{l}\text { 流域森林づ } \\
\text { くり委員会 }\end{array}$ & $\begin{array}{l}\text { 該当する市町 } \\
2011 \text { 年現在 }\end{array}$ & $\begin{array}{c}\text { 森林面積 } \\
\text { (国有林を } \\
\text { 含屯) } \\
\text { ha }\end{array}$ & $\begin{array}{c}\text { 森林率 } \\
\% \\
\%\end{array}$ & $\begin{array}{c}\text { 民有林 } \\
\text { 人工林率 } \\
\\
\%\end{array}$ & $\begin{array}{c}\text { 民有林 } \\
\text { 人工林 } \\
\text { 蓄積 } \\
\mathrm{m}^{3} / \mathrm{ha}\end{array}$ \\
\hline 大津 & 大津市 & 25,157 & 54 & 40 & 248 \\
\hline 南部 & $\begin{array}{l}\text { 草津市, 守山市, } \\
\text { 栗東市, 野洲市, } \\
\text { 甲賀市, 湖南市 }\end{array}$ & 39,951 & 49 & 53 & 202 \\
\hline 東近江 & $\begin{array}{l}\text { 近江八幡市, 東 } \\
\text { 近江市, 日野町, } \\
\text { 竜王町 }\end{array}$ & 31,462 & 43 & 30 & 199 \\
\hline 湖東 & $\begin{array}{l}\text { 彦根市, 愛荘町, } \\
\text { 豊郷町, 甲良町, } \\
\text { 多賀町 }\end{array}$ & 15,248 & 39 & 54 & 245 \\
\hline 湖北 & 長浜市, 米原市 & 53,117 & 57 & 40 & 261 \\
\hline 高島 & 高島市 & 36,966 & 53 & 47 & 294 \\
\hline 全県 & & 201,904 & 50 & 44 & 243 \\
\hline
\end{tabular}

haの違いが見られる.

各流域森林づくり委員会は，滋賀県が 2006 年に 定めた「流域森林づくり委員会設置要綱」［6] に準 拠して設置されている。「要綱」では，委員会の目 的を「流域の森林つくりの在り方，進め方等につい て，県，市町等への提案その他の活動を行ら」とし ている. 委員については，「定数は 15 名以内とし, 地域住民，森林所有者，森林づくりに関する活動を 行ら団体等によって構成し，県が選任または公募す る」と定めている.

\section{（3）アンケート調査}

平成 21 年度までの委員 67 名に対して，アンケー ト調査票を送付した。調査期間は，2010 年 11 月 7 日〜 12 月 17 日である. 有効回答数は 39 件（有効 回収率は 58\%）であった。

アンケートの内容は，第 1 部では各回答者の属性 及び委員会への参加状況・満足度，第 2 部では委員 会活動に対する評価を問らものである.

第 2 部の質問項目は, 群馬県の提示した『NPO と行政との協働に関する指針』[7]を参照して作成 した。すなわち，協働の前提条件および原則を援用 し，運営方法の評価項目を設定し，それぞれについ ての評価を回答者に尋祆ることによって測定した.

ここで設定した評価基準とは，以下の 7 つの項目 である。

（1）公共性の認識

(2) 相互理解

（3）目的の明確化・共有化 
（4）自立性・対等性の尊重

(5) 信頼関係の構築

（6）役割・責任の明確化

（7）透明性の確保

\section{3. 結果}

\section{（1）聞き取り調査}

聞き取り調査の結果, 流域森林づくり委員会の活 動の全体像が明らかになった（表 2)。2006 年ころ から活動が開始して打り，いずれの委員会でも開催 頻度は 2 か月に 1 回である。東近江の 4 名を除いて は，委員数は 12 名から 15 名である. そうした共通 点とは別に，それぞれの流域森林づくり委員会の特 徵も明らかになった（各委員会を匿名として扱らた め, 表 2 に抢いては，以下で述べる特徴については あえて記載していない). 特に, 独自事業の有無, 役割分担の有無について，違いが見られた。すなわ ち, 話し合い以外に, 独自に森林管理の調査や木材 製品の開発などの独自の事業を行ったか否か，とい

\section{表 2. 各委員会の特徵}

\begin{tabular}{|c|c|c|c|c|c|c|}
\hline 流域名 & 大津 & 南部 & 東近江 & 湖東 & 湖北 & 高島 \\
\hline 設立年 & 2007 & 2006 & 2006 & 2007 & 2006 & 2007 \\
\hline 開催頻度 & $\begin{array}{c}2 \text { か月に } \\
1 \text { 回 }\end{array}$ & $\begin{array}{c}2 \text { か月に } \\
1 \text { 回 }\end{array}$ & $\begin{array}{c}2 \text { か月に } \\
1 \text { 回 }\end{array}$ & $\begin{array}{c}2 \text { か月に } \\
1 \text { 回 }\end{array}$ & $\begin{array}{c}2 \text { か月に } \\
1 \text { 回 }\end{array}$ & $\begin{array}{c}2 \text { か月に } \\
1 \text { 回 }\end{array}$ \\
\hline 委員数 & 13 & 14 & 4 & 12 & 14 & 15 \\
\hline $\begin{array}{l}\text { 代表者の } \\
\text { 有無 }\end{array}$ & あり & あり & なし & あり & あり & あり \\
\hline $\begin{array}{l}\text { 分科会の } \\
\text { 有無 }\end{array}$ & なし & なし & なし & あり & あり & なし \\
\hline $\begin{array}{l}\text { 広報誌の } \\
\text { 有無 }\end{array}$ & なし & なし & あり & あり & あり & なし \\
\hline $\begin{array}{l}\text { その他の } \\
\text { 特徵 }\end{array}$ & $\begin{array}{l}\text { 現地調査 } \\
\text { など }\end{array}$ & $\begin{array}{l}\text { フォーラ } \\
\text { ムの開催 } \\
\text { など }\end{array}$ & $\begin{array}{l}\text { ワーク } \\
シ ョ ッ フ ゚ \\
\text { など }\end{array}$ & $\begin{array}{l}\text { フォーラ } \\
\text { ムの開催 } \\
\text { など }\end{array}$ & $\begin{array}{l}\text { フォーラ } \\
\text { ムの開催 } \\
\text { など }\end{array}$ & $\begin{array}{l}\text { びわ湖環 } \\
\text { 境ビジネ } \\
\text { スメッセ } \\
\text { への参加 }\end{array}$ \\
\hline
\end{tabular}

表 3. 回答者の年齢

$\left.\begin{array}{ccc}\hline \hline \text { 年齢 } & \text { 人数 } & \% \\ \hline 10 \text { 代 } & 0 & 0 \% \\ 20 \text { 代 } & 1 & 3 \% \\ 30 \text { 代 } & 2 & 5 \% \\ 40 \text { 代 } & 2 & 5 \% \\ 50 \text { 代 } & 14 & 36 \% \\ 60 \text { 代 } & 14 & 36 \% \\ 70 \text { 代 } & 6 & 15 \% \\ 80 \text { 代 } & 0 & 0 \% \\ \text { 計 } & 39 & 100 \%\end{array}\right\} 51 \%$

ら点で委員会別に違いが見られる。 また，分科会を 設置して，役割分担を行ったかどらか，についても 違いが見られた.さらには, 中心人物が強いリーダー シップを発揮して委員会活動を引っ張ったかどう か，といら点についても違いがあった.

\section{（2）アンケート調査：記述統計}

委員の特徵を見ていさたい。まず，年齢別にみる と 60 代以上が過半を占めて打り，高年層の比重が 大きいことがわかる（表 3）.

次に職業・所属について概観する（表 4)。回答 者全体として見ると,それぞれの職業 (所属) グルー プからまんべんなく構成されていることがわかる.

次に，委員会参加の満足度について検討する（表 5). 約 7 割の回答者が満足を示している（=「満足 できた」+「ある程度満足できた」).

満足度を職業（所属）別に見た（図 1)。製材業・ 建築業などの企業者および NPO・ボランティア団 体の間で, やや満足度が低いことがらかがえる.

満足度を尋ねた際に，「満足できた・ある程度満 足できた」と「あまり満足できなかった・満足でき なかった」についての理由を自由記述で述べても らった．満足できたと答えた意見の中には，「色々 な立場の人と交流ができた」といら点が多く（29 件中 7 件) 挙がっていた。 他には，「森林の現状を

表 4. 回答者の職業（所属）

\begin{tabular}{|c|c|c|}
\hline 年歯令 & 人数 & $\%$ \\
\hline 森林所有者 & 6 & $15 \%$ \\
\hline 森林組合 & 6 & $15 \%$ \\
\hline 製材業・建築業など & 6 & $15 \%$ \\
\hline $\mathrm{NPO}$ ・ボランティア団体 & 7 & $18 \%$ \\
\hline 研究者 & 2 & $5 \%$ \\
\hline 学生 & 0 & $0 \%$ \\
\hline その他 & 11 & $28 \%$ \\
\hline 不明 & 1 & $3 \%$ \\
\hline 計 & 39 & $100 \%$ \\
\hline
\end{tabular}

表 5. 委員会に参加しての満足度

\begin{tabular}{lcc}
\hline \hline \multicolumn{1}{c}{ 満足度 } & 人数 & $\%$ \\
\hline 満足できた & 8 & $21 \%$ \\
ある程度満足できた & 19 & $49 \%$ \\
あまり満足できなかった & 12 & $31 \%$ \\
満足できなかった & 0 & $0 \%$ \\
計 & 39 & $100 \%$ \\
\hline
\end{tabular}


$\begin{array}{lllllllllll}0 \% & 10 \% & 20 \% & 30 \% & 40 \% & 50 \% & 60 \% & 70 \% & 80 \% & 90 \% & 100 \%\end{array}$

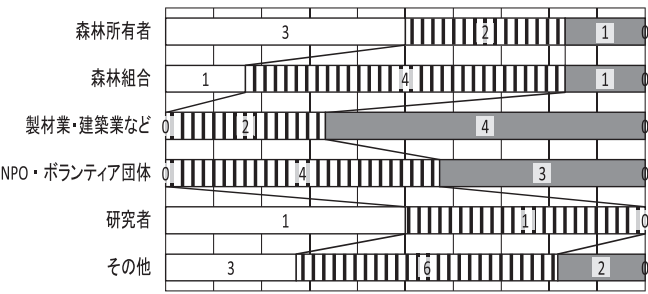

$\begin{array}{ll}\text { 口満足できた } & \text { 口ある程度満足できた } \\ \text { 口あまり満足できなかった } & \text { 口満足できなかった }\end{array}$

図 1. 職業（所属）別の満足度の分布

ロできたロある程度できた ロあまりできなかった ロできなかった

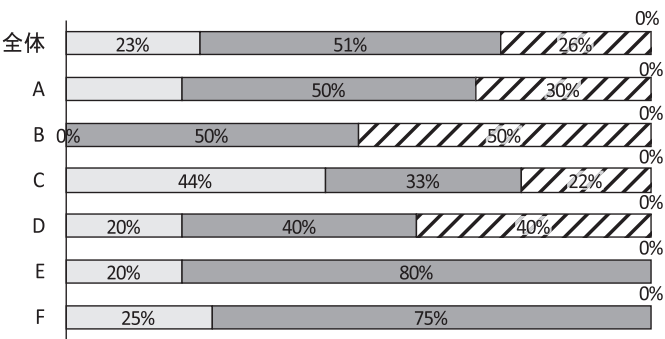

図 2.「提言活動」における公共性

把握できた」等の意見もあった（29 件中 5 件). 反 対に，満足できなかったという人の意見では，「実 現への見通しが見えてこなかった」なぞの点が挙げ られていた（11 件中 6 件）。

委員会の活動を大別し，県・市への提言活動（提 言活動）と県民啓発活動（啓発活動）飞分けて，前 述の 7 つ評価項目に基づいて評価を依頼した.

たとえば，「提言活動」に扔忷る「公共性」（具体 的については，「広く地域住民のことを考光て委員 会に参加できている」）を満足できたかぞらか，「で きた」「ある程度できた」「あまりできなかった」「で きなかった」の 4 段階で評価を求めた（図 2 ).

図 2 亿示すように，回答者全体では，23\%が「で きた」と評価し，51\%が「ある程度できた」とし， 26\%が「あまりできなかった」とし，「できなかった」 とするのは $0 \%$ ある， A， B， C， D ， E，Fとアル ファベットで示しているバー (帯) は各委員会での 評価の分布を表している，各委員会を特定せず，匿 名扱いとするため, アルファベットによる記述とし た、それぞれの委員会で，分布に差異があることが 分かる。

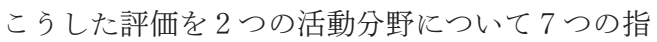

表 6. 委員会活動の評価（点数）

\begin{tabular}{|c|c|c|c|c|c|c|c|c|}
\hline 活動分野 & 評価項目 & 全体 & A & B & $\mathrm{C}$ & $\mathrm{D}$ & $\mathrm{E}$ & $\mathrm{F}$ \\
\hline \multirow{7}{*}{ 提 } & 公共性 & 3.0 & 2.9 & 2.5 & 3.2 & 2.8 & 3.2 & 3.3 \\
\hline & 相互理解 & 3.3 & 3.4 & 2.8 & 3.3 & 3.6 & 3.2 & 3.8 \\
\hline & 信頼関係の構築 & 3.0 & 3.3 & 2.3 & 2.7 & 3.0 & 3.2 & 3.5 \\
\hline & 自立性・対等性の尊重 & 3.1 & 3.1 & 3.0 & 2.7 & 3.6 & 3.2 & 3.5 \\
\hline & 目的の明確化 - 共有化 & 3.1 & 3.3 & 2.7 & 3.0 & 3.2 & 3.2 & 3.3 \\
\hline & 役割・責任の明確化 & 3.1 & 3.0 & 2.5 & 3.1 & 3.6 & 3.0 & 3.3 \\
\hline & 情報交換 & 2.4 & 2.2 & 2.0 & 2.3 & 2.4 & 2.6 & 3.3 \\
\hline \multirow{7}{*}{ 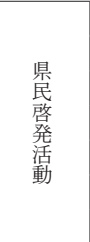 } & 公共性 & 2.6 & 2.5 & 2.0 & 3.0 & 2.0 & 3.0 & 3.0 \\
\hline & 相互理解 & 2.9 & 3.2 & 2.2 & 3.2 & 3.0 & 3.0 & 2.5 \\
\hline & 信頼関係の構築 & 2.9 & 3.1 & 2.0 & 2.9 & 2.8 & 3.0 & 4.3 \\
\hline & 自立性・対等性の尊重 & 3.0 & 3.0 & 2.0 & 3.2 & 3.4 & 3.2 & 3.5 \\
\hline & 目的の明確化・共有化 & 3.0 & 3.1 & 2.3 & 3.3 & 3.2 & 3.2 & 2.5 \\
\hline & 役割・責任の明確化 & 2.9 & 2.7 & 2.2 & 3.4 & 3.4 & 3.0 & 2.5 \\
\hline & 情報交換 & 2.5 & 2.6 & 1.7 & 2.4 & 2.8 & 2.8 & 3.0 \\
\hline
\end{tabular}

標で行った．その結果， $14(=2 \times 7)$ の評価指標が 得られた。

次に委員会別，評価基準別に評価結果を見る．評 価を全体として簡単に見渡すため, 回答を点数化し， 回答者全体，各委員会別に平均值を求めた。具体的 には，「できた」といら回答には 4 点，「ある程度で きた」には 3 点，「あまりできなかった」には 2 点， 「できなかった」には1点を与えることとした，そ の結果を表 6 に示す.

「提言活動」の分野で,評価基準ごとに比較すると, 回答者全体（「全体」のコラム［列]）では，相互理 解の評価 (3.3 点) が高く, 情報交換の評価が低い $(2.4$ 点)。一方，「県民啓発活動」の分野では，自立性・ 対等性の尊重及び目的の明確化・共有化が高く（と もに 3.0 点)，公共性（2.6 点）打よび情報交換（2.5 点）が低い。

活動分野の間で, 共通する評価基準で比較すると, ほとんぞの場合，提言活動の方に高い点数を与えて いる（例外は，「情報交換」で，提言活動が 2.4 点， 県民啓発活動が 2.5 点).

委員会間で比較しても，ばらつきが見られる，表 3 の中で，全体より当該委員会が高い点数を得てい る場合は，そのセルを灰色で塗りつぶしている.

\section{(3) クロス集計}

次に示す 3 件の仮説を検証するため, クロス集計 を実施した。

仮説 1 : 独自事業の有無と評価の間には相関がある. 仮説 2 : 役割分担の有無と評価の間には相関がある. 仮説 3 : 中心人物の強力なリーダーシップの有無と 
評価の間には相関がある.

聞き取り調査の結果より, 各委員会の特徵（独自 事業の有無, 役割分担の有無, 中心人物の強いリー ダーシップの有無）を判断し，以下の分析に用いた. また，評価については，「ある程度できた」（3 点）以

\section{表 7. 独自事業の有無と評価のクロス集計}

\begin{tabular}{|c|c|c|}
\hline & 評価項目 & クラメール連関係数 \\
\hline \multirow{7}{*}{$\begin{array}{l}\text { 提 } \\
\text { 言 } \\
\text { 活 } \\
\text { 動 }\end{array}$} & （1）公共性 & 0.23 \\
\hline & (2) 相互理解 & 0.04 \\
\hline & （3）信頼関係の構築 & 0.04 \\
\hline & （4）自立性・対等性 & 0.12 \\
\hline & (5) 目的の明確化 - 共有化 & 0.08 \\
\hline & （6）役割・責任の明確化 & 0.15 \\
\hline & （7）情報公開 & 0.08 \\
\hline \multirow{7}{*}{$\begin{array}{l}\text { 県 } \\
\text { 䇾 } \\
\text { 活 } \\
\text { 動 }\end{array}$} & （1）公共性 & $0.38(+)$ \\
\hline & （2）相互理解 & $0.29(+)$ \\
\hline & （3）信頼関係の構築 & 0.06 \\
\hline & (4) 自立性・対等性 & $0.29(+)$ \\
\hline & (5) 目的の明確化 - 共有化 & $0.29(+)$ \\
\hline & （6）役割・責任の明確化 & $0.35(+)$ \\
\hline & （7）情報公開 & 0.23 \\
\hline
\end{tabular}

表 8. 役割分担の有無と評価のクロス集計

\begin{tabular}{|c|c|c|}
\hline & $\begin{array}{l}\text { 評価項目 } \\
\end{array}$ & クラメール連関係数 \\
\hline \multirow{7}{*}{$\begin{array}{l}\text { 提 } \\
\text { 活 } \\
\text { 動 }\end{array}$} & （1）公共性 & 0.19 \\
\hline & (2) 相互理解 & 0.18 \\
\hline & (3) 信頼関係の構築 & $0.28(+)$ \\
\hline & （4）自立性・対等性 & $0.35(+)$ \\
\hline & (5) 目的の明確化 - 共有化 & 0.17 \\
\hline & (6) 役割・責任の明確化 & 0.21 \\
\hline & （7）情報公開 & 0.23 \\
\hline \multirow{7}{*}{$\begin{array}{l}\text { 県 } \\
\text { 啓 } \\
\text { 萿 } \\
\text { 動 }\end{array}$} & （1）公共性 & 0.16 \\
\hline & (2) 相互理解 & 0.16 \\
\hline & (3) 信頼関係の構筑 & 0.11 \\
\hline & （4）自立性・対等性 & $0.35(+)$ \\
\hline & (5) 目的の明確化 - 共有化 & 0.16 \\
\hline & （6）役割・責任の明確化 & 0.15 \\
\hline & （7）情報公開 & $0.30(+)$ \\
\hline
\end{tabular}

表 9. 強いリーダーシップの有無と評価のクロス集計

\begin{tabular}{|c|c|c|}
\hline & 評価項目 & クラメール連関係数 \\
\hline \multirow{7}{*}{$\begin{array}{l}\text { 提 } \\
\text { 言 } \\
\text { 活 } \\
\text { 動 }\end{array}$} & （1）公共性 & 0.07 \\
\hline & (2) 相互理解 & 0.17 \\
\hline & (3) 信頼関係の構築 & $0.41(-)$ \\
\hline & (4) 自立性・対等性 & $0.25(-)$ \\
\hline & (5) 目的の明確化 - 共有化 & 0.17 \\
\hline & (6) 役割・責任の明確化 & 0.21 \\
\hline & （7）情報公開 & 0.23 \\
\hline \multirow{7}{*}{$\begin{array}{l}\text { 県 } \\
\text { 棨 } \\
\text { 発 } \\
\text { 活 } \\
\text { 動 }\end{array}$} & （1）公共性 & 0.06 \\
\hline & (2) 相互理解 & $0.27(-)$ \\
\hline & (3) 信頼関係の構築 & $0.47(-)$ \\
\hline & (4) 自立性・対等性 & 0.07 \\
\hline & (5) 目的の明確化 - 共有化 & 0.03 \\
\hline & (6) 役割・責任の明確化 & 0.04 \\
\hline & （7）情報公開 & 0.09 \\
\hline
\end{tabular}

上の評価を当該基準に与えた場合，その基準につい て達成されたものとし(1 と評価)「あまりできなかっ た」（2 点）以下の評価を与えた場合，その基準につ いては達成されていないものと（0 と評価）した.

まず，独自事業の有無と評価の関係を検証する. クラメール連関係数による分析結果を表 4 に示す.

な拈，黒くセルに色を付けているのは，やや強い 相関が認められたもので連関係数は 0.25 以上であ る. 灰色でセルに色を付けているのは，やや弱い相 関が認められたもので連関係数は 0.1 以上である.

クラメール連関係数は, 負の值をとらない。やや 強い正または負の相関関係を示すため, 連関係数の 後ろのカッコ内にプラスまたはマイナスの符号を記 載した。

表 7 より分かるように，独自活動の有無は県民啓 発活動の評価と多くの場合, 関係している.

次に，役割分担の有無と評価の関係について検証 する. 表 8 とクロス集計の結果を示す。「提言活動」 「県民啓発活動」ともに，2つの基準について，正 の相関が確認された。

最後に, 中心人物の強いリーダーシップの有無と 評価の相関について検証を执こなう。この関係につ いてのクロス集計の結果を表 9 亿示す.

強いリーダーシップの存在は, 提言活動において は，信頼関係の構築，自立性・対等性の評価につい て，負の相関を有している，県民啓発活動について は，相互理解，信頼関係の構築の評価について，負 の相関を有している。

\section{4. 考察}

滋賀県に扬ける流域森林づくり委員会の特徵とし ては， 60 代以上の高年者層が過半を占めているこ とが挙げられる。これは，事務局が主体となる選出 の過程で, 現在, 地域で活躍している人物, 各グルー プの主導的立場に立つ人物を多く選ぶこととなり， このような結果になったと考えられる。 また，森林 に関心を持つ年齢層が高くなって招り（[8] 参照）, その結果，高年者層が委員会でも多くなっていると も考光ら光る。

委員の職業 (所属) 構成はバランスがとれて打り, 各種類別に大きな偏りはない。これも，事務局が委 員を選定する際，職業（所属）のバランスを考慮し た結果だと考えらえる。 
多くの委員が，委員会の参加に満足している．こ の結果は，額面通りに取ることもできる一方で，委 員会に参加したことに対する事後的な正当化の結果 とも解釈できる。製材業・建築業などの企業者执よ びNPO・ボランティア団体からの参加者の間で, 比較的満足度が低い.「会議ばかりで進展がなかっ た」といった自由記述なども参照すると，スピード 感をもって具体的な成果を求める希望が満たされな かったことが原因でないかと考えられる。

「提言活動」と「県民啓発活動」に大別した場合， 全般的に，「県民啓発活動」に対しての評価が低く なっている。この違いは， 2 か月に 1 回と時間的に 制約されたもとでは，行政などへの提言は比較的簡 単になしらるのに対し, 県民の啓発は期待した水準 を達成しづらかったと考えることができる.

クロス集計の結果から，独自の事業をすることが, 県民啓発活動に対する評価を高める要因となってい ることがわかる. 分かり易く森林に関わる事項を県 民に伝えるらえで，具体的な目に見觉る事業による 発信が有効だと委員が考えていることを示している.

また，委員会内で役割分担がなされた場合，提言 活動では「信頼性の構築」「自立性・対等性」, 県民 啓発活動では「自立性・対等性」「情報の公開」の 面で評価を高めることが分かった。

強いリーダーシップは, 提言活動に拈いてパ フォーマンスを高める可能性がある一方で, 委員会 内部の交流については，必ずしも有効に働かないこ とが判明した．限られた時間の中で，結果を出すこ とと各委員の思いを共有することとの間にトレード オフが働いていることが推測できる.

\section{5. 結論}

本稿では，滋賀県に扣いて試みられている県民協 働の森林づくり活動について，参加者のアンケート 調査を中心に分析を行った。 参加者の特徵および満 足度が明らかになった。 また，運営方法の違いによ る，参加者の評価の違いも見いだされた，

今後，住民との協働を実施するらえで，これらの 事項を参考にすることが必要であろら.

年齢層の偏りについて，意識的に調整することが 求められる. 若年層の意見・立場の協働活動への反 映が不十分である恐れがあり，どのように若年層を 取り込むべきか検討すべきである。たとえば, 現在,
滋賀県では森林環境学習が「やまのこ」事業として 県下の小学 4 年生を対象として 1997 年度より実施 されている [9]. また，全国的には「緑の少年団」 が 1960 年より活動を行っている [10].こうした活 動の発展形として「緑の青年団」(仮称) が形成され, そこから協働への参画が行われるならば，青年層の 意見・立場の反映が容易となり，協働により大きな 発展の可能性が現れるであろら.

運営方法についても，本稿はいくつかの示唆を与 える，県民啓発活動として，外部にアピールする独 自事業を展開することをまず考えなくてはならな い.そらした事業を軸として，組織体制も考える必 要がある。分科会などによる，役割分担を適切に行 ら必要がある。最後に, リーダ一の立ち位置につい て再検討が必要だろら。

本稿では，滋賀県に扣ける森林・林業分野での協 働活動について，参加者の視点から，その成果を検 討した。他都道府県での事例との比較対照が，将来 の研究課題として挙げられる。ささらには，農業，環 境など他分野での事例との比較検討も森林・林業分 野の協働の特質を明らかにするために興味深い課題 として考えられるであろら。

\section{参考文献}

[1] 羽貝正美「基礎自治体の新しい地平 : 参画と協 働によるローカルガバナンスの刷新と自治体再 構築」, 羽貝正美編『自治と参画・協働 : ロ一 カルガバナンスの再構築』, 学芸出版社, 2007 年, pp. 8-30.

[2] 林野庁「森林 - 林業基本計画」(平成 23 年 7 月 26 日閣議決定)，2011 年.

[3]柿澤宏昭「地域に颃ける森林政策の主体をど ら考えるか:市町村レベルを中心にして」，『林 業経済研究』50(1),2004 年, pp. 3-14.

[4]柿澤宏昭「地域材による住宅建築をめぐる協 働関係の形成に関する考察: 十勝地方のカラ マッの家づくりを対象として」, 『林業経済研 究』53(3),2007 年, pp. 12-20.

[5]岡田久仁子「第 4 章 森林環境税の形成と住 民参加」，岡田久仁子著『環境亡分権の森林管 理：イギリスの経験・日本の課題』，日本林業 調査会, 2007 年, pp. 141-174.

[6]滋賀県『流域森林つくり委員会設置要綱』, 
2006 年.

[7]群馬県『NPO と行政との協働に関する指針』, 2008 年.

[8］高橋卓也「滋賀県南部流域住民の森林に対す る意識についてーアンケート調査による構造 の解明一」, 『農林業問題研究』第 45 巻第 2 号 (第 175 号)，2009 年，pp. 218-223.
[9] 滋賀県「森林環境学習『やまのこ』事業 / 滋賀 県」<http://www.pref.shiga.jp/d/mori/shinrinzei jigyo/yamanoko/>2011-11-9 ダウンロード, c. 2011 年.

[10］国土緑化推進機構「緑の少年団」<http://www. green.or.jp/fukyu/kids/youth/>2011-11-9 ダ ウン ロード， c. 2011 年.

（受理日：2012 年 3 月 9 日） 